\title{
ANALISIS PENERAPAN MODEL PEMBELAJARAN DEBATE PADA MATA KULIAH BUDAYA MASYARAKAT DEMOKRATIS DALAM MENINGKATKAN KEMAMPUAN BERFIKIR KRITIS MAHASISWA PGSD
}

\author{
Yuli Mulyawati $^{*}$, Fitri Anjaswuri ${ }^{\left.a^{*}\right)}$ \\ ${ }^{a)}$ Universitas Pakuan, Bogor, Indonesia \\ *)e-mail korespondensi : fitriajaswuri@unpak.ac.id
}

Riwayat Artikel : diterima: 29 Januari 2020; direvisi: 06 Februari 2020; disetujui: 16 Februari 2020

\begin{abstract}
Abstrak. Penelitian ini merupakan penelitian deskriptif kualitatif Berdasarkan hasil penelitian yang dilakukan oleh peneliti bahwa penerapan model pembelajaran debate parlemen dapat meningkatkan kemampuan berpikir kritis yaitu sebuah kemampuan yang dimiliki setiap orang untuk menganalisis ide atau gagasan ke arah yang lebih spesifik untuk mengejar pengetahuan yang relevan tentang dunia dengan melibatkan evaluasi bukti. Kemampuan berpikir kritis sangat diperlukan untuk menganalisis suatu permasalahan hingga pada tahap pencarian solusi untuk menyelesaikan permasalahan tersebut, kemungkinan-kemungkinan jawaban lain berdasarkan analisis dan informasi yang telah didapat dari suatu permasalahan. Observer memberikan nilai rata-rata 74, 8 dengan kriteria sangat baik, observer 2 memberikan nilai 75,0 dengan kriteria sangat baik, observer 3 memberikan nilai 75,2 dengan kriteria sangat baik. observer memberikan nilai rata-rata 82,35 dengan kriteria sangat baik, observer 2 memberikan nilai 82,55 dengan kriteria sangat baik, observer 3 memberikan nilai 82,25 dengan kriteria sangat baik. Maka dapat disintesiskan bahwa Penerapan Model Pembelajaran Debate pada Mata kuliah Budaya Masyarakat Demokratis dapat meningkatkan Kemampuan Berfikir Kritis. Mahasiswa PGSD
\end{abstract}

Kata Kunci: pembelajaran debate; kemampuan berpikir kritis

\begin{abstract}
ANALYSIS OF THE APPLICATION OF DEBATE LEARNING MODEL IN DEMOCRATIC CULTURAL CULTURE COURSES IN ENHANCING THE CRITICAL THINKING ABILITY. PGSD STUDENTS.

Abstract. This research is a qualitative descriptive study based on the results of research conducted by researchers that the application of parliamentary debate learning models can improve critical thinking skills, which is the ability that everyone has to analyze ideas or ideas in a more specific direction to pursue relevant knowledge about the world by involving evaluation of evidence. The ability to think critically is needed to analyze a problem to the stage of finding a solution to solve the problem, the possibility of other answers based on analysis and information that has been obtained from a problem. Observer gives an average value of 74, 8 with very good criteria, observer 2 gives a value of 75.0 with very good criteria, observer 3 gives a value of 75.2 with very good criteria. observer gives an average value of 82.35 with very good criteria, observer 2 gives a value of 82.55 with very good criteria, observer 3 gives a value of 82.25 with very good criteria. So it can be synthesized that the Application of Debate Learning Model in the Democratic Cultural Culture course can improve the Critical Thinking Ability. PGSD students.
\end{abstract}

Keywords: learning debate; critical thinking skills

\section{PENDAHULUAN}

Mahasiswa sebagai generasi penerus bangsa harus mengetahui dan memahami pentingnya budaya demokrasi bagi negara demokrasi. Menjadi tanggung jawab kita selaku warga negara untuk meyakini, menanam dan menerapkan budaya demokrasi di berbagai lingkungan kehidupan. Dalam rangka membentuk warga negara yang meyakini, menanamkan dan menerapkan budaya demokrasi pembelajaran dalam perkuliahan Budaya Masyarakat Demokrasi haruslah mengarah kepada keterampilan berfikir kritis mahasiswa dalam menyikapi permasalahan yang berkaitan dengan demokrasi.

Permasalahan tentang demokrasi semakin runcing muncul kepermukaan yang apabila salah dalam menyikapinya akan memecah belah persatuan dan kesatan bangsa. Kemampuan mahasiswa dalam menyikapi hal-hal tersebut perlu kiranya mempunyai kemampuan daya analitis, kritis dan logis dalam mencermati masalah yang sedang muncul.

Adapun saat ini kemampuan berdebat di kalangan mahasiswa dirasa sangat kurang hal ini dikarenakan mahasiswa kurang memahami pentingnya kemampuan berdebat. Kemampuan berargumentasi dari mahasiswa yang masih kurang, terbiasa menerima informasi tentang budaya masyarakat demokrasi dalam bentuk teori dan konsepkonsep saja. Sedangkan kemampuan berdebat yang menuntut untuk dapat berfikir analitis, kritis, dan logis kurang dikembangkan.

Untuk dapat melatih kemampuan berfikir kritis dan juga melatih mahasiswa untuk dapat mengemukakan pendapatnya secara proposonal maka diperlukanan kemampuan dalam berdebat. Karena dalam budaya demokratis kemampuan berdebat dengan baik mencerminkan kemampuan mengemukakan pendapat dengan baik. 
Manusia adalah makhluk yang unik sekaligus rumit. Dengan keunikan dan kerumitannya usaha untuk memahami manusia dengan segala aktifitasnya tidak pernah berhenti. Menurut seorang filsuf Yunani Kuno manusia adalah Animal Sociale. Manusia adalah binatang yanghidup bersama. Ia tidak hanya hidup ada bersama dengan yang lain, tetapi hanya bisa hidup dalam kebersamaan dengan yang lain. Manusia juga sering disebut Zoon Politicon, manusia adalah binatang yang mempunyai kepentingan. Kepentingan itu lebih luas dari sekedar kebutuhan. Adanya berbagai kepentingan dalam dalam konteks kehidupan bersama sering kali memunculkan konflik. Manusia juga disebut sebagai makhluk konfliktif. (Beachler [1])

Pendidikan demokrasi ini menurut Azra [2] secara substantif menyangkut sosialisasi, internalisasi dan aktualisasi konsep, sistem, nilai, budaya dan praktek demokrasibagi warga negara, sehingga menjadi warga negara yang kritis, partisipatif, demokratis dan beradab. Hal senada dikatakan Zamroni [3] bahwa Pendidikan Kewarganegaraan sebagai pendidikan demokrasi adalah suatu proses yang dilakukan oleh lembaga pendidikan di mana seseorang mempelajari orientasi, sikap dan perilaku politik sehingga yang bersangkutan memiliki political knowledge, awareness, attitude, political efficacy, social trust dan political participation serta kemampuan mengambil keputusan politik secara rasional dan menguntungkan bagi dirinya, juga bagi masyarakat. Pandangan terakhir Zamroni di atas, menguatkan bahwa pendidikan demokrasi secara inheren merupakan substantif dan sub-ordinatif pendidikan kewarganegaraan dalam persekolahan (school civics). Dalam konteks ini, Winataputra [4] berpendapat bahwa pendidikan kewarganegaraan di persekolahan (school civics) memiliki peranan strategis dalam mewujudkan pengembangan budaya kewarganegaraan demokratis, karena pendidikan kewarganegaraan merupakan salah satu modal dasar dalam mewujudkan kehidupan bermasyarakat yang berbudaya dan beradab.

Santrock [5] juga mengemukakan pendapatnya bahwa berpikir adalah memanipulasi atau mengelola dan mentransformasi informasi dalam memori. Berpikir sering dilakukan untuk membentuk konsep, bernalar dan bepikir secara kritis, membuat keputusan, berpikir kreatif, dan memecahkan masalah.

Jika berpikir merupakan bagian dari kegiatan yang selalu dilakukan otak untuk mengorganisasi informasi guna mencapai suatu tujuan, maka berpikir kritis merupakan bagian dari kegiatan berpikir yang juga dilakukan otak. Menurut Santrock [5], pemikiran kritis adalah pemikiran reflektif dan produktif, serta melibatkan evaluasi bukti. Jensen [6] berpendapat bahwa berpikir kritis berarti proses mental yang efektif dan handal, digunakan dalam mengejar pengetahuan yang relevan dan benar tentang dunia. Cece Wijaya [7] juga mengungkapkan gagasannya mengenai kemampuan berpikir kritis, yaitu kegiatan menganalisis ide atau gagasan ke arah yang lebih spesifik, membedakannya secara tajam, memilih, mengidentifikasi, mengkaji dan mengembangkannya ke arah yang lebih sempurna.

Berdasarkan beberapa pendapat ahli tersebut, dapat diambil kesimpulan mengenai pengertian kemampuan berpikir kritis yaitu sebuah kemampuan yang dimiliki setiap orang untuk menganalisis ide atau gagasan ke arah yang lebih spesifik untuk mengejar pengetahuan yang relevan tentang dunia dengan melibatkan evaluasi bukti. Kemampuan berpikir kritis sangat diperlukan untuk menganalisis suatu permasalahan hingga pada tahap pencarian solusi untuk menyelesaikan permasalahan tersebut., kemungkinan-kemungkinan jawaban lain berdasarkan analisis dan informasi yang telah didapat dari suatu permasalahan. Berpikir kritis berarti melakukan proses penalaran terhadap suatu masalah sampai pada tahap kompleks tentang "mengapa" dan "bagaimana" proses pemecahannya.

Debat adalah suatu keterampilan berargumentasi dengan mengadu atau membandingkan pendapat secara berhadap-hadapan (Antar Semi [8]). Sedangkan Menurut Melvin [9], sebuah debat bisa menjadi metode berharga untuk meningkatkan pemikiran dan perenungan, terutama jika siswa diharapkan mengemukakan pendapat yang bertentangan dengan diri mereka sendiri. Ini merupakan strategi debat yang secara aktif melibatkan tiap siswa didalam kelas tidak hanya mereka yang berdebat. Teknik debat merupakan salah satu teknik pembelajaran yang sangat membantu dalam upaya meningkatkan kemampuan akademik siswa. Teknik debat adalah alat untuk mencapai suatu tujuan dalam pembelajaran dengan cara menyajikan topik kontroversi yang menarik untuk diperdebatkan sehingga dapat mendukung siswa untuk melatih keterampilan berargumentasi, berbicara dan menyimak, selain itu teknik debat juga dapat melatih siswa dalam mempertahankan pendapat dengan berusaha menolak pendapat lawan dengan menggunakan alasan-alasan yang masuk akal dan logis.

\section{METODE PENELITIAN}

Penelitian ini menggunakan metode penelitian deskriptif kualitatif. Penelitian dilaksanakan di Prodi PGSD Fakultas Keguruan dan Ilmu Pendidikan Unversitas Pakuan Bogor. Penelitian ini dilaksanakan pada bulan April sampai dengan bulan Juni 2019 semester genap Tahun Akademik 2018/2019. Subjek penelitian ini adalah Mahasiswa PGSD Semester 6 tahun akademik semester genap tahun 2018/2019. Adapun teknik pengumpulan data yang dilakukan dalam penelitian ini adalah observasi, wawancara, dokumentasi, dan instrument penelitian. Teknik pemeriksaan keabsahan data dalam penelitian ini yaitu dengan menggunakan triangulasi. Triangulasi adalah teknik pemeriksaan keabsahan data dengan memanfaatkan sesuatu yang lain diluar data untuk keperluan pengecekan atau sebagai pembanding terhadap data tersebut. Dalam penelitian ini, peneliti menggunakan dua jenis triangulasi yaitu triangulasi sumber dan triangulasi teknik [10]. 


\section{HASIL DAN PEMBAHASAN}

Berdasarkan hasil penelitian penerapan model pembelajaran debate parlemen di interpretasikan kedalam kriteria memperoleh data sebagai berikut :

Tabel 1 Nilai Rata-rata Kelas dan kriterianya

\begin{tabular}{|c|c|c|}
\hline Oberver & Rata-rata & Kriteria \\
\hline Observer 1 & 74,8 & Sangat Baik \\
\hline Observer 2 & 75,0 & Sangat Baik \\
\hline Observer 3 & 75,2 & Sangat Baik \\
\hline
\end{tabular}

Berdasarkan Tabel 1. Menunjukan observer memberikan nilai rata-rata 74, 8 dengan kriteria sangat baik, observer 2 memberikan nilai 75,0 dengan kriteria sangat baik, observer 3 memberikan nilai 75,2 dengan kriteria sangat baik.

Apabila dibuatkan dalam bentuk diagram histogram akan terlihat seperti gambar 1 .

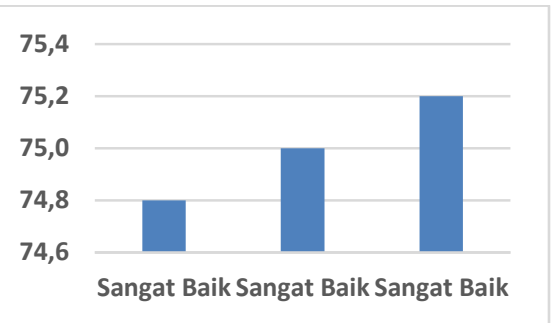

Gambar 1. Diagram Histogram kriteria penerapan model pembelajaran debate parlemen

Penerapan model pembelajaran yang baik dapat berkontribusi dalam pelaksanaan demokrasi yang sedang berlangsung di Indonesia. Dengan penerapan model pembelajatran debate parlemen mahasiswa dapat menganalisis permasalahan demokrasi secara komfrehensif. debate parlemen merupakan salah satu penerapan yang menuntut mahasiswa dapat berfikir kritis, kreatif, analitis dan argumentative.

Berdasarakan Tabel 5.2 menunjukan observer memberikan nilai rata-rata 74, 8 dengan kriteria sangat baik, observer 2 memberikan nilai 75,0 dengan kriteria sangat baik, observer 3 memberikan nilai 75,2 dengan kriteria sangat baik. Berdasarkan Tabel 5.4 menunjukan observer memberikan nilai rata-rata 82,35 dengan kriteria sangat baik, observer 2 memberikan nilai 82,55 dengan kriteria sangat baik, observer 3 memberikan nilai 82,25 dengan kriteria sangat baik.

Berdasarkan hasil penelitian diatas dapat disintesiskan bahwa Penerapan Model Pembelajaran Debate pada Mata kuliah Budaya Masyarakat Demokratis dalam Meningkatkan Kemampuan Berfikir Kritis. Mahasiswa PGSD.Pemahaman konsep dan Keterampilan Proses sains meningkat setelah siswa mengalami proses pembelajaran tugas kelompok [11].

\section{SIMPULAN}

Penerapan model pembelajaran debate parlemen dapat meningkatkan kemampuan berpikir kritis yaitu sebuah kemampuan yang dimiliki setiap orang untuk menganalisis ide atau gagasan ke arah yang lebih spesifik untuk mengejar pengetahuan yang relevan tentang dunia dengan melibatkan evaluasi bukti. Kemampuan berpikir kritis sangat diperlukan untuk menganalisis suatu permasalahan hingga pada tahap pencarian solusi untuk menyelesaikan permasalahan tersebut, kemungkinan jawaban lain berdasarkan analisis dan informasi yang didapat dari suatu permasalahan.

Observer memberikan nilai rata-rata 74,8 dengan kriteria sangat baik, observer 2 memberikan nilai 75,0 dengan kriteria sangat baik, observer 3 memberikan nilai 75,2 dengan kriteria sangat baik. observer memberikan nilai rata-rata 82,35 dengan kriteria sangat baik, observer 2 memberikan nilai 82,55 dengan kriteria sangat baik, observer 3 memberikan nilai 82,25 dengan kriteria sangat baik. Maka dapat disintesiskan bahwa Penerapan Model Pembelajaran Debate pada Mata kuliah Budaya Masyarakat Demokratis dapat meningkatkan Kemampuan Berfikir Kritis. Mahasiswa PGSD.

\section{REFERENSI}

[1] Beachler, Jean. (2001). Democracy An Analatical Survey. Terjemahan Bern Hidayat UNESCO, Paris.

[2] Azra, A. (2002). Paradigma Baru Pendidikan Nasional : Rekonsiliasi dan Demokratisasi. Jakarta : PT Kompas Media Nusantara.

[3] Zamroni. (2002). Demokrasi dan Pendidikan Dalam Transisi : Perlunya Reorientasi Pengajaran Ilmu-Ilmu Sosial di Sekolah Menengah. Pidato Pengukuhan Guru Besarpada FIS UNY Yogyakarta.

[4] Winataputra, U.S. (2008). Multikulturalisme Bhinneka Tunggal Ika dalam Perspektif Pendidikan Kewarganegaraan sebagai Wahana Pembangunan Karakter Bangsa Indonesia. Acta Civicus. 2, (1), 1-16.

[5] Santrock, Jhon W (2011) Perkembangan anak usia dini, Jakarta : Selemba Humanika

[6] Jensen. 2011. Pembelajaran berbasis-otak Paradigma pengajaran baru Jakarta: PT Indeks.

[7] Cece, Wijaya. 2010. Pendidikan Remidial: Sarana Pengembangan Mutu Sumber Daya Manusia. Bandung: PT Remaja Rosdakarya

[8] Antar Semi. (2009). Trampil berdiskusi dan berdebate. Titian ilu Bandung

[9] Melvin Silberman L. (2011). Active Learning 101 Cara Belajar Siswa Aktif. Bandung: Nuansa.

[10] Sugiyono. 2009. Metode Penelitian Kuantitatif, Kualitatif, R\&D , Bandung: Alfbeth. CV

[11] Y. Suchyadi and N. Karmila. 2019. The Application Of Assignment Learning Group Methods Through Micro Scale Practicum To Improve Elementary School Teacher Study Program College Students , Skills And Interests In Following Science Study Courses, JHSS (Journal Humanit. Soc. Stud., vol. 03, no. 02, pp. 95-98, 2019. 